\title{
THE EVALUATION OF DRINKING WATER QUALITY OF AGRI TOWN USING CILIATES AS BIOINDICATORS
}

\author{
Gina Raluca Kerkmann ${ }^{1 *}$, Hysen Mankolli $^{2}$ \\ $1^{*}$ Expert in Biology, Agri Turkey; \\ ${ }^{2}$ Expert in Ecology, Plainfield, Illinois, USA; \\ *Corresponding author Gina Raluca Kerkmann, email: ralukagyna@gmail.com;
}

Received May, 2018; Accepted May, 2018; Published June, 2018;

DOI: https://doi.org/10.31407/ijees8321

UOI license: http://u-o-i.org/1.01/ijees/27892877

\begin{abstract}
Water represents an important resource for the population of each country, the most important ecosystem of Turkey from this point of view being the reservoir from Yazici dam. In 2015, there started some researches using ciliates as saprobic indicators of drinking water delivered to consumers. The present paper proposes an introduction in ciliates fauna of this area; in the 34 collected samples of water and sediments, there were determined 25 species most of them being cosmopolitan, euryhaline and bacterivorous. The technical scheme of the sewage treatment plant is presented in a simplified manner, the turbidity of the water being carefully monitored. In the drinking water delivered to consumers, there were not identified any ciliates which confirms the high drinking water quality and the efficiency of the treatment plant. The present paper shows basic details about the wastewater treatment station and evolution of water turbidity in each of its compartments. In the future, the management of this resource needs to be improved as well as the population perception regarding environmental protection in general.
\end{abstract}

Key words: Yazici dam, Ciliates, drinking water 